Islam and the Challenge of Civilization 
This page intentionally left blank 


\section{Islam and the Challenge of Civilization}

ABDELWAHAB MEDDEB

Translated by Jane Kuntz 
Copyright (C) 2013 Fordham University Press

All rights reserved. No part of this publication may be reproduced, stored in a retrieval system, or transmitted in any form or by any means-electronic, mechanical, photocopy, recording, or any other-except for brief quotations in printed reviews, without the prior permission of the publisher.

This work was originally published in French as Pari de civilisation, (C) Éditions du Seuil, 2009.

Cet ouvrage a béneficié du soutien des Programmes d'aide à la publication de l'Institut Français.

This work, published as part of a program of aid for publication, received support from the Institut Français.

Ouvrage publié avec le concours du Ministère français chargé de la Culture-Centre National du Livre.

This work has been published with the assistance of the French Ministry of Culture-National Center for the Book.

Fordham University Press has no responsibility for the persistence or accuracy of URLs for external or third-party Internet websites referred to in this publication and does not guarantee that any content on such websites is, or will remain, accurate or appropriate.

Fordham University Press also publishes its books in a variety of electronic formats. Some content that appears in print may not be available in electronic books.

Library of Congress Cataloging-in-Publication Data

Meddeb, Abdelwahab.

Islam and the challenge of civilization / Abdelwahab

Meddeb ; translated by Jane Kuntz. p. $\mathrm{cm}$.

Includes bibliographical references.

I. Islam-2Ist century. 2. Islamic civilization.

3. Muslims-Non-Muslim countries. 4. Islamic renewal.

I. Kuntz, Jane. II. Title.

BPI6I.3.M43 2013

297.2'70905I-dc23

2012050168

Printed in the United States of America

$\begin{array}{llllllll}\text { I5 } & \text { I4 } & \text { I } 3 & 5 & 4 & 3 & 2 & \text { I }\end{array}$

First edition 